\title{
PEDAGOGY
}

\section{CHARACTERISTICS OF THE CONTENT OF}

PEDAGOGICAL CONDITIONS FOR EDUCATION OF

PHYSICAL QUALITIES OF EDUCATIONAL SUBJECTS

"SCHOOL-SECTION" IN THE PROCESS OF EXTRACURRICULAR WORK FROM PHYSICAL EDUCATION

\author{
${ }^{I}$ Senior Teacher, Tetyana Polulyashchenko, \\ ${ }^{2}$ Candidate of Pedagogical Sciences, associate professor, \\ professor of the department Yuri Polulyashchenko
}

Ukraine, Starobilsk, DZ "Lugansk National University the name of Taras Shevchenko"

${ }^{I}$ Senior Lecturer of the Department of Sports Disciplines educational-scientific institute of physical education and sport

${ }^{2}$ Director of the educational-scientific institute of physical education and sports

DOI: https://doi.org/10.31435/rsglobal_wos/30062019/6553

\section{ARTICLE INFO}

Received: 08 April 2019

Accepted: 11 June 2019

Published: 30 June 2019

\section{KEYWORDS}

upbringing,

physical qualities,

pedagogical conditions,

physical training

\begin{abstract}
Content of pedagogical conditions of education of physical qualities of subjects of the educational space, "School-Section" in the process of extracurricular work on physical education. The article deals with topical issues related to the creation of certain pedagogical conditions that promote the upbringing of physical qualities of pupils of the school. The concept of the "condition" in the scientific sources is revealed. The importance of creating certain pedagogical conditions is proved, as a qualitative organization of the educational process on physical education of the children of the school depends on them. The pedagogical conditions that allow to consider extracurricular activity of students of the basic school as the activity having significant educational potential for solving modern problems of physical education in institutions of general secondary education, as well as for development of physical qualities of students, namely: creation of a single educational space "School - Section ", aimed at uniting the educational potential of the subjects of the educational environment for the organization of extracurricular classes on cycling sports and the education of the physical qualities of the pupils of the school; raising the level of pedagogical skill of the trainer-teacher; scientific and methodical provision of the process of raising the physical qualities of cyclists; organization of psychological and pedagogical support for students of the main school in the process of extracurricular activities in cycling.
\end{abstract}

Citation: Polulyaschenko T., Polulyaschenko Y. (2019) Characteristics of the Content of Pedagogical Conditions for Education of Physical Qualities of Educational Subjects "School-Section" in the Process of Extracurricular Work from Physical Education. International Academy Journal Web of Scholar. 6(36). doi: 10.31435/rsglobal_wos/30062019/6553

Copyright: (C) 2019 Polulyaschenko T., Polulyaschenko Y. This is an open-access article distributed under the terms of the Creative Commons Attribution License (CC BY). The use, distribution or reproduction in other forums is permitted, provided the original author(s) or licensor are credited and that the original publication in this journal is cited, in accordance with accepted academic practice. No use, distribution or reproduction is permitted which does not comply with these terms.

Introduction. According to the research of scientific, monographic and periodical literature, materials of scientific and practical conferences testifies that in accessible psychological and pedagogical sources insufficient attention is paid to the issues of organization of training work with 
children in conditions of extracurricular activities, and especially the education of physical qualities of students of educational institutions of education.

The study was conducted to study the problems of extracurricular work in physical education in educational institutions found that the education and development of children in the ability to manifest physical qualities is based on the general laws of sports training. A number of scholars believe that it is necessary to create pedagogical conditions in order to properly educate and develop the physical qualities of young athletes during extracurricular training sessions in selected sports. We consider the development of physical qualities of pupils who have developed in the process of education and purposeful sports training of the child's motor skills, which determine its ability to successfully perform certain motor activity. The education of physical qualities in our opinion refers to the pedagogical process, aimed at the physical development of the child's personality in order to increase its level. What became the basis for the study and development of pedagogical conditions for the education of physical qualities of primary school students in the process of extracurricular activities in cycling.

Research results. The question of developing and implementing pedagogical conditions for the education of the physical qualities of schoolchildren remains open, which negatively affects the achievement of successful results in cycling and other forms of motor activity.

By studying pedagogical conditions it can be argued that under the pedagogical conditions one can understand the factors influencing the process of achieving the goal, which are divided into: external: positive relationships between teacher (trainer) and student; objectivity assessment of the educational process; place of study, premises, climate, etc.; and internal: individual characteristics of students (health, character properties, experience, skills, skills, motivation, etc.). Therefore, it can be argued that any pedagogical process can be successfully carried out subject to certain conditions, therefore, it is necessary to identify and scientifically substantiate the pedagogical conditions of development of physical qualities of schoolchildren.

The notion of content "condition" in scientific sources has a number of interpretations. S. Ozhegov believes that this meaning of the term "condition" has several concepts: "... this is a fact from which anything depends; a requirement put forward by one of the parties to the agreement; oral or written agreement on anything; rules established in any sphere of life and activity; an environment in which something is happening ... "[7, p. 626].

In the explanatory dictionary of the Ukrainian language it is stated that the condition is a "necessary circumstance that makes possible the realization, creation, formation of something, or promotes something" [7, p. 632]. The conditions usually include external or internal circumstances, something from which anything depends. In the philosophical sense of the conditions determine the external circumstances that determine the emergence of a certain phenomenon, the result of purposeful activity [5, p. 15]. Without such circumstances, the desired phenomenon can not occur.

According to A. Bezpalko, in pedagogical literature, pedagogical conditions are defined as "... a set of objective and subjective factors that are necessary to ensure the effective functioning of all components of the pedagogical system ..." [1, p. with. 33].

The analysis of philosophical, psychological and pedagogical scientific literature shows that the problem of substantive and meaningful analysis of the concept of "pedagogical conditions" is considered by domestic and foreign scientists from various aspects (A. Aleksyuk, A. Dymin, V. Luzan, R. Gurevich, V. Klochko, M. Kozyar, V. Monakhov, V. Strelnikov, N. Tvrezovsky, L. Filippov, etc.).

In our opinion, it is more acceptable to assert that the disclosure of the content of the term "pedagogical conditions" refers to the circumstances associated with the organization of educational process in the institution of education, with that external educational environment, in which there is a cognitive, educational and educational activity of schoolchildren, aimed at forming the knowledge, skills and abilities necessary for them in their everyday activities.

An analysis of scientific sources indicates that pedagogical conditions are external circumstances that ensure the functioning and development of a process that requires some sort of organization and organization. Organization in this case is understood by us as a process of achieving certainty in the external and internal systems of the systems, necessary to ensure the stability of these systems in a changing environment [12, p.163; 8, p. 93]. 
Thus, under the pedagogical conditions, scientists understand the peculiarities of the organization of the educational process, which are aimed at creating a favorable foundation for the achievement of the goals of education and education of the individual.

In their studies, the pedagogical conditions are considered as the peculiarities of the organization of the educational process on the physical education of children of the main school, which determines the results of the education of their physical qualities, the comprehensive development of the personality of the students; the result of purposeful selection, design and application of certain content, pedagogical techniques, forms, methods, aimed at raising the physical qualities of the pupils of the main school in the process of extracurricular work on cycling.

Conditions of upbringing of physical qualities in the process of extracurricular training in cycling include the implementation of the principles of accessibility and activity, dynamism and consistency, compliance of the load not only with the state of physical fitness, but also with motor qualities; weight and regulation and compliance with loads and the adequacy of their application; the actions of the teacher should be aimed at the rational construction of the process of physical education. The problem of the influence of the environment on the educational process of the younger generation was seen in scholarly works by such scholars as O. Globa, A. Makarenko, Y. Manuilova, L. Novikova, S. Savchenko, V. Sukhomlinsky, L. Shelestova, I. Shendrik and many others. The indicated scholars in their work considered the educational environment as a multidimensional socio-pedagogical phenomenon, connected in a single whole with various communicative mechanisms, such that has a significant situational influence on the development of value orientations of the person, relations and behavior, which are actualized in the processes of development, consumption and the dissemination of socio-cultural values.

The study of the works of the above-mentioned scholars on the correlation of the notions of the educational environment and the educational space made it possible to conclude that the educational space is a pedagogically advisable social-subject environment that contains a system of interconnected factors, conditions, possibilities, means, united the efforts of the subjects of the educational process in different types of activities and which has an integrated influence on the development of the individual and promotes its socialization. It is through the creation of a pedagogically expedient educational space that the effectiveness of the educational process increases.

I. Shenderyk determines the educational space as a form of unity of people that formed during their joint activity, during which the caregiver through direct or indirect interaction creates the conditions and opportunities for the establishment and development of pupils [13, p.96].

An analysis of the theory and practice of the studied problems we have identified pedagogical conditions that can be considered extracurricular activities secondary school pupils as an activity that has significant educational potential to solve current problems of physical education in institutions of secondary education and for the development of physical qualities of students, namely: the creation of a single educational space "School-Section", aimed at combining the educational potential of the subjects of the educational environment for the organization of extracurricular activities in cycles ednoho sport and physical qualities education secondary school pupils; raising the level of pedagogical skill of the trainer-teacher; scientific and methodical provision of the process of raising the physical qualities of cyclists; organization of psychological and pedagogical support for students of the main school in the process of extracurricular activities in cycling.

The conducted study on the study of pedagogical conditions for the education of the physical qualities of educational institutions in educational institutions in extracurricular work on physical education made it possible to identify the characteristics and content of the subjects of the educational space "School - Section". tabl. 1 (characteristic of the content of the subjects of the educational space, "School - Section"). 
Table 1. Characteristics of the content of the subjects of the educational space, "School - Section"

\begin{tabular}{|c|c|}
\hline $\begin{array}{l}\text { Institutions, } \\
\text { services at different } \\
\text { levels }\end{array}$ & The content of the work \\
\hline $\begin{array}{l}\text { Department } \\
\text { Youth and Sports } \\
\text { (physical culture } \\
\text { and sports) of the } \\
\text { regional state } \\
\text { administration }\end{array}$ & $\begin{array}{l}\text { - Participation in realization on the territory of the region of the state policy in } \\
\text { the field of physical education and sports; } \\
\text { - promotion of the development of recognized sports in Ukraine, in particular cycling; } \\
\text { - organization and conducting of sports and sports events among the general } \\
\text { population; } \\
\text { - identification, support and development of gifted children, organization of } \\
\text { competitions, competitions, sports events, tournaments, etc., aimed at raising the } \\
\text { general physical level of children and youth; } \\
\text { - promotion of the preservation and development of a network of athletic and } \\
\text { sports institutions, taking measures for their personnel recruitment and } \\
\text { strengthening the material and technical base; } \\
\text { - approval of the provisions on competitions and competitions and training- } \\
\text { training meetings; } \\
\text { - preparation of the composition of the teams of the region according to the } \\
\text { kinds of sports; organization of training of athletes for participation in } \\
\text { competitions of different levels; } \\
\text { - study, generalization and dissemination of best practices in physical education } \\
\text { and sports, conducting methodological and scientific workshops, conferences } \\
\text { and other events; } \\
\text { - attraction of funds of enterprises, institutions and organizations for the } \\
\text { development of physical culture and sports, etc. }\end{array}$ \\
\hline Schools & $\begin{array}{l}\text { - Formation of knowledge about healthy lifestyles, skills and abilities for } \\
\text { independent exercises, as well as engagement in systematic sports, other types } \\
\text { of motor activity; } \\
\text { - training of students in major motor activities (running, jumping, throwing, } \\
\text { climbing, swinging, balance, skiing); } \\
\text { - development of physical qualities (strength, endurance, speed, agility, flexibility); } \\
\text { - education of moral-volitional qualities (discipline, honesty, will, etc.); } \\
\text { organization of extra-curricular work: sports sections and circles of various } \\
\text { sports, in particular cycling, additional optional classes, holding mass sports- } \\
\text { artistic holidays and days of health, various competitions and competitions; } \\
\text { - Formation of interest in cycling in students; health promotion of students; } \\
\text { promotion of a healthy lifestyle and physical development of the student; } \\
\text { studying the technique of riding a bicycle on different routes); } \\
\text { - work with parents }\end{array}$ \\
\hline $\begin{array}{l}\text { Section } \\
\text { Sports" }\end{array}$ & $\begin{array}{l}\text { - Dominating and polishing of bicycle sport equipment; } \\
\text { - purposeful development (upbringing) of physical qualities (strength, } \\
\text { endurance, speed, agility, flexibility) to maintain the necessary physical form, } \\
\text { preparation for competitions and increase of sports skills; } \\
\text { - education of moral-volitional qualities (discipline, honesty, will, tolerance to } \\
\text { rivals, etc.); } \\
\text { - control and management of the development of physical qualities in the } \\
\text { preparation of highly skilled cyclists; } \\
\text { - continuous monitoring of the level of development of physical qualities and } \\
\text { abilities for cycling; } \\
\text { - preparation and participation in various cycling competitions of different levels }\end{array}$ \\
\hline Families & $\begin{array}{l}\text { - Interaction with the school and the section, implementation of the } \\
\text { recommendations of the teacher and coach in support of the mode of life and } \\
\text { nutrition of a young athlete; } \\
\text { - support in competitions; } \\
\text { - creation of conditions for development of physical qualities in home } \\
\text { conditions. }\end{array}$ \\
\hline
\end{tabular}


Conclusions. 1. For the optimal modeling of the educational space, the diagnosis of the environment, the consideration of its positive and negative potentials, are of particular importance; study of the needs and motives of the collective (schools, institutions, centers, organizations) and individual (children, teachers, parents) participants; taking into account the peculiarities of the activities of informal associations of children and adults in the environment, part of which should become educational space.

2. The basic requirements for the creation of the educational space "School-Section" are the following: pedagogy and psychologization as the ability to take into account all external and internal influences on the child in a complex, and at the same time create a spiritual and creative development environment, neutralizing them from negative and strengthening positive ones; openness to the society (to act in cooperation with the family, the public); involvement of children in solving socially significant and personal life problems, forming of experience of civic behavior; development of creative potential of all subjects of the educational process; encouraging students to independently solve their own life problems in an unstable society; liveliness as the ability to provide the child with the opportunity to arrange his own life, to create collective and interpersonal relationships; the pedagogical culture of teachers and educators, the inalienable features of which are humanity, intelligence, tolerance, understanding, ability to interact; pedagogical protection and support of children in solving their life problems and in individual self-development, ensuring their personal integrity and security; Selfrealization of a person in the personal, professional and social spheres of life.

\section{REFERENCES}

1. Bezpalko O. V. Orhanizatsiia sotsialno-pedahohichnoi roboty z ditmy ta moloddiu u terytorialnii hromadi : teoretyko-metodychni osnovy : [monohrafiia] / O. V. Bezpalko. - K. : Naukovyi svit, 2006. - 363 s. , s. 33].

2. Bekh I. D. Vykhovannia osobystosti: Skhodzhennia do dukhovnosti: nauk. vydannia / I. D. Bekh. - K. : Lybid, 2006. - 272 s.. Bezpalko. - K. : Naukovyi svit, 2006. - 363 s., s. 33].

3. Bondarchuk E. Y. Osnovы psykholohyy y pedahohyky : kurs lektsyi // E. Y. Bondarchuk, L. Y. Bondarchuk. - [3-e yzd., steretyp.]. - K. : MAUP, 2002. - 168 s.

4. Vedmedenko B.F. Teoriia i metodyka vykhovannia interesu v uchniv do zaniat fizychnoiu kulturoiu. Dys..dokt.ped.nauk. - K., APN Ukrainy, 2005. - $701 \mathrm{~s}$.

5. Zhydko Yu.S. Formyrovanye potrebnosty $\mathrm{v}$ neprerbvnom fyzycheskom sovershenstvovanyy starsheklassnykov obshcheobrazovatelnыkh shkol: avtoref. dys. na zdobuttia nauk, stupenia kand. ped. nauk: 13.00.01 / Yu.S. Zhydko. - Ryha, 2000. - 24 s

6. Poluliashchenko T.L. Проблеми фізичного виховання учнів основної школи в процесі позакласних занять у сучасній науковій психолого-педагогічній літературі./ T.L. Poluliashchenko: [Naukovyi zhurnal Khersonskoho derzhavnoho universytetu «Innovatsiina pedahohika»] Vypusk 7 Tom 1. Odesa. 2018r. S.160-135. [Elektronnyi resurs] - http://www.innovpedagogy.od.ua/7-1-eng.

7. Ozhehov S. Y. Slovar russkoho yazыka / S. Y. Ozhehov. - M. : Russkyi yazыk, 1987. - 748 s., s. 626.

8. Poluliashchenko T. L. Vozrast nachala zaniatyi detei velosypednum sportom / T. L. Poluliashchenko // Materyalы VII Mezhdunarodnoi nauchno-praktycheskoi konferentsyy «Olympyiskyi sport, fyzycheskaia kultura, zdorove natsyy v sovremennukh uslovyiakh», Luhansk 28 travnia 2010. S.112-117..

9. Poluliashchenko T. L. Osnovы postroenyia protsessa fyzycheskoi podhotovky v makrotsykle honshchykov, kotorbe spetsyalyzyruiutsia v kross-kantry na эtape nachalnoi podhotovky / Scintific Youth:Priorities of the Word Science/ Festschrift of the IV International Scienrific-Practical Conference. Published: 20 february 2014. Luhansk: "LNU", LLC Virtualnaya realnost. The Author(s). Scientific Youth $\backslash S Y \backslash P W S I C Y S I U A . I C-$ S1LLNU_2020 S. 100 sovremennukh uslovyiakh», Luhansk 28 travnia 2010. S.112-117.

10. Poluliashchenko T. L. Formuvannia fizychnykh yakostei shkoliariv starshoi shkoly pid vplyvom zaniat velosypednym sportom / T. L. Poluliashchenko // Naukovyi visnyk Donbasu. - Starobilsk. - 2014. - № 4 (28)- Rezhym dostupu - http://nvd.luguniv.edu.ua/archiv/NN28/24.pdf.

11. Shendryk Y. H. Samorazvytye lychnosty v kontekste proektyrovanyia obrazovanyia / Y. H. Shendryk // Pedahohyka. - 2004. - № 4. - S. 98-114

12. Poluliashchenko T. L. Pedahohichni peredumovy vykhovannia fizychnykh yakostei uchniv v pozaklasnii roboti z fizychnoho vykhovannia i sportu / T. L. Poluliashchenko // Pedahohichni nauky. Zbirnyk naukovykh prats vypusk LXXX. № 80 Tom 3.2017 S.91-96 Khersonskoho derzhavnoho universytetu [Elektronnyi resurs] http://ps.stateuniversity.ks.ua/file/issue_80/part_3/20.pdf. 